\title{
Online Appendix to Domestic Value Added in Exports: Theory and Firm Evidence from China
}

Hiau Looi Kee (World Bank) and Heiwai Tang (Johns Hopkins University)

\section{Data Description}

The main data set for this paper covers the universe of Chinese import and export transactions in each month between 2000 and 2007. It reports values (in US dollars) of a firm's exports (and imports) at the HS 8-digit level (over 7000 products) to each destination (from each source) country. We drop trading companies (intermediaries) in our sample, using the methods proposed by Ahn, Khandelwal, and Wei (2011) to identify them. This level of disaggregation is the finest for empirical studies in international trade - i.e., transactions at the firm-product-country-month level.

Processing trade has been playing a significant role in driving China's export growth. From 2000 to 2007, processing exports have increased by over four folds from 138 billion USD to 680 billion USD with the share of processing exports in total exports held steadily around 55 percent, as shown in Figure A1. In addition, Table A1 shows that, the U.S. consistently ranked as the top destination, accounting for about 25 percent of Chinese total processing exports. Following the U.S. is Hong Kong SAR, China, which accounted for slightly over 20 percent of the total. Japan has been the third largest market for Chinese processing exports, but its prominence has declined from 18 percent in 2000 to 10 percent in 2007. Processing exports are widespread among China's top 10 export destinations, as seen in Figure A2. It accounted for 63 percent of Chinese exports to the U.S. in 2007 and 81 percent for Hong Kong SAR, China, the highest share among the top 10 destinations.

We present in Figure A3 the share of processing exports in 2007 by industry sector, 
according to the United Nations groupings of HS2 categories. There exists a substantial heterogeneity in the prevalence of processing exports across industries. The share is about 20 percent for the "wood \& articles" sector (HS2 =6 -14) and is over 80 percent for the "machinery, mechanical, and electrical equipment" sector (HS2 = 84-85).

The advantage of focusing on processing exporters is that we need not worry about their imports for final consumption, as by definition, all imports in processing trade have to be used as intermediate inputs. ${ }^{52}$ However, not all processing exporters import for their own use. Some of them import for other processing firms, which also implies that some processing firms must export more than what their imported materials can support. We develop systematic rules to identify processing firms that potentially import from and export for other firms. To this end, we merge the customs transaction data with the firm-level data from the Annual Surveys of Industrial Firms conducted by China's National Bureau of Statistics (NBS hereafter). The surveys cover all state-owned enterprises (SOEs) and non-state-owned firms that have sales above 5 million yuan in a given year. ${ }^{53}$ The NBS data contain detailed information for most of the standard balance sheet information, such as firm ownership, output, value added, industry code (480 categories), exports, employment, original value of fixed asset, and intermediate inputs. Tables A2 and A3 present the percentages of firms and sales that are covered by the merged data. Table A4 presents the industry's median of firm materials-to-sales ratios.

\footnotetext{
${ }^{52}$ Manova and $\mathrm{Yu}$ (2013) examine how financial constraints affect exporters positions in global supply chains in China and thus their profits. In this paper, we simply take advantage of the special features of the processing regime without getting into the details about firms' transition from one regime to another.

${ }^{53}$ The industry section in the official statistical yearbooks of China is constructed based on the same data source. The unit of analysis is a firm, and not the plant, but other information in the survey suggests that more than $95 \%$ of all observations in our sample are single-plant firms. 5 million yuan is roughly exchanged to 600,000 US dollars during the sample period.
} 


\section{A Transforming Chinese I/O Tables to One Based on UN Indus- try Code}

1. Use the concordance from China's National Bureau of Statistics to match multiple IO codes with multiple HS 6-digit codes (revision 2002).

2. Match multiple HS6 codes to multiple UN industry sector codes (20 of them).

3. For each IO code, pick the UN code that has the largest number of HS6 shared. This will guarantee that all IO codes will be covered.

4. For UN codes that are matched with multiple IO codes, manually choose a unique UN code for the match. It happens in only one case.

5. Then add up the values of intermediate inputs for each pair of upstream-downstream relationship. A matrix of 20 groups by 20 groups will be built.

6. Recompute the IO coefficients based on the UN industry sector classification.

\section{B Computing Domestic Upstream Variety}

To compute domestic upstream variety, we use the weighted average of the number of HS6 products exported by non-processing firms across all upstream industries as a proxy for domestic upstream varieties, since data on domestic varieties are not available. The belief is that a firm's export product scope is a subset of its domestic product scope. ${ }^{54}$ Specifically, we compute the weighted average of the number of upstream varieties by $V_{j t}=\sum_{i=1}^{I} s_{i j} V_{i t}$, where $s_{i j}$ is the share of industry $i^{\prime} s$ goods used in total input costs of industry $j$, according to the Chinese input-output table for 2002. $V_{i t}$ is the number of HS6 products exported by

\footnotetext{
${ }^{54}$ There could be export varieties that were not sold domestically or vice versa. There could also be domestic varieties produced by non-exporters that were not exported. In these regards, our proxy should be considered as a lower bound of the number of domestic varieties.
} 
non-processing firms in industry $i$ in year $t$. Since the HS classifications have changed twice (in 2002 and 2007, respectively) during our sample period, we use the concordance file created by Cebeci et al. (2012) to define a consistent set of varieties over time. As reported in Table A5, the number of varieties available to the downstream processing exporters is increasing over time for most industries. Some industries have systematically higher input varieties (e.g. machinery, mechanical, and electrical equipment). This industry-specific feature is already controlled for by industry fixed effects in the regressions.

\section{Computing Upstream Input Tariffs}

Computing an industry's upstream tariffs involves two steps. For each upstream industry, input tariffs are measured as a weighted average of tariffs facing all input suppliers to that industry. Specifically, we obtain the share of industry $i$ 's inputs in total material cost of industry $j, s_{i j}$, from the Chinese IO table for 2002. Then for each industry $j$, we compute the weighted average of input tariffs as $\widetilde{\tau}_{j t}=\sum_{i=1}^{I} s_{i j} \tau_{i t}$, where $\tau_{i t}$ is the average tariff rate for industry $i$ in year $t$ and $I$ is the total number of industries. Finally, for each downstream industry $k$, we use the IO coefficients again to compute the weighted average of upstream

input tariffs $\widetilde{\tau}_{k t}^{U}=\sum_{j=1}^{I} s_{j k} \widetilde{\tau}_{j t}$. The idea to use the IO tables twice is that we need the measure of tariffs facing domestic input suppliers, not downstream exporters. For example, a garment firm uses fabrics, zippers and buttons. Fabrics firms use cotton yarns, zipper firms use steel, and button firms use plastics. Thus, the upstream input tariff for a garment firm is a weighted average tariff rates on cotton yarns, steel and plastics.

\section{Computing Industry-specific Exchange Rate Indices}

We use the Tornqvist method to construct an industry-specific time-varying exchange rate. For each industry $j$, let $I_{j t}$ be the set of common countries firms in industry $j$ import from 
in two consecutive years, $t$ and $t-1$. Denote country $c$ 's currency price of a yuan in year $t$ and $t-1$ by $E_{c t}$ and $E_{c t-1}$; and denote country $c$ 's shares in industry $j^{\prime} s$ total imports in year $t$ and $t-1$ by $s_{c j t}$ and $s_{c j, t-1}$. The industry-specific rate of yuan appreciation with respect to the countries from which industry $j$ imports in year $t$ is defined as

$$
\triangle \ln E_{j t}=\sum_{c \in I_{j t}} \frac{1}{2}\left(s_{c j t}+s_{c j, t-1}\right)\left(\ln E_{c t}-\ln E_{c, t-1}\right) .
$$

Using this weighted average of appreciation rates, we define the industry-specific exchange rate for imports as

$$
E_{j t}=E_{j, t-1} \exp \left(\triangle \ln E_{j t}\right)
$$

with $E_{j t}$ normalized to 1 in the base year (i.e., 2000) or any starting year for each industry.

\section{E Computing Industry-specific Domestic Input Price Indices}

Computing the input price indices involves two steps. First, we use the Tornqvist method to construct an industry-specific time-varying domestic input price indices. For each industry $j$ (15 of them), let $I_{j t}$ be the set of common sub-industries in two consecutive years, $t$ and $t-1$. Denote sub-industry $s$ 's output price index in year $t$ and $t-1$ by $P_{s t}$ and $P_{s, t-1}$; and denote the share of sub-industry $s$ 's sales in industry $j^{\prime} s$ total sales in year $t$ and $t-1$ by $\omega_{s j t}$ and $\omega_{s j, t-1}$. Data on output price indices at the 4-digit sector level (based on China's NBS classification) are obtained from Brandt, Van Biesebroeck, and Zhang (2012). ${ }^{55}$ The industry-specific rate of output price inflation in year $t$ is defined as

$$
\triangle \ln \widetilde{P}_{j t}=\sum_{s \in I_{j t}} \frac{1}{2}\left(\omega_{s j t}+\omega_{s j, t-1}\right)\left(\ln P_{s t}-\ln P_{s, t-1}\right) .
$$

\footnotetext{
${ }^{55}$ http://www.econ.kuleuven.be/public/N07057/CHINA/appendix/
} 
Using this weighted average of inflation rates, the sector-specific output price level is defined as

$$
\widetilde{P}_{j t}=\widetilde{P}_{j, t-1} \exp \left(\triangle \ln \widetilde{P}_{j t}\right),
$$

with $\widetilde{P}_{j t}$ normalized to 1 in 2000 .

The second step is to compute the weighted average of $\widetilde{P}_{j t}$, with weights equal to the coefficients from the Chinese IO table for 2002. The goal is to compute the average domestic prices facing processing firms in industry $j$. Specifically, for each industry $j$, the weighted average of input prices is $P_{j t}^{D}=\sum_{k=1}^{J} a_{k j} \widetilde{P}_{k t}$, where $a_{k}$ is the share of industry $k$ goods in total material costs for production of a unit of industry $j$ goods and $J$ is the number of industries. Notice that $P_{j t}^{D}$ varies across time purely due to the variation in $\widetilde{P}_{j t}$, since $a_{k j}$ is fixed throughout the sample.

\section{F Computing Industry-specific Imported Input Price Indices}

To compute the imported input indices, we use the Tornqvist method to construct an industry-specific time-varying import price indices based on firm-level imports from the customs transaction data. For each industry $j$ (15 of them), let $I_{j t}$ be the set of common product (at the HS 8-digit level) in two consecutive years, $t$ and $t-1$. Denote product $s$ 's import prices in year $t$ and $t-1$ by $p_{s t}^{I}$ and $p_{s, t-1}^{I}$; and denote the share of product $s$ 's imports in industry $j^{\prime} s$ total imports in year $t$ and $t-1$ by $\varpi_{s j t}$ and $\varpi_{s j, t-1}$. Product-level import prices (by processing firms only) are computed as total import value divided by total quantity of import at the HS8 level, using customs transaction-level data. Then sector-specific rate of import price inflation in year $t$ is defined as

$$
\triangle \ln \widetilde{P}_{j t}^{I}=\sum_{j \in I_{j t}} \frac{1}{2}\left(\varpi_{s j t}+\varpi_{s j, t-1}\right)\left(\ln p_{s t}^{I}-\ln p_{s, t-1}^{I}\right)
$$


Using this weighted average of inflation rates, the sector-specific import price level is defined as

$$
\widetilde{P}_{j t}^{I}=\widetilde{P}_{j, t-1}^{I} \exp \left(\triangle \ln \widetilde{P}_{j t}^{I}\right)
$$

with $\widetilde{P}_{j t}^{I}$ normalized to 1 in 2000. Table A6 reports the ratio of the imported material price index to the domestic material price index across industry-years.

\section{Theoretical Derivation of Firm DVAR (the Cobb- Douglas Case)}

In the main text, we derive the theoretical expression of firm $D V A R$ based on a translog production function. In this section, we use a more convenient form of production function - the Cobb-Douglas production function, as the basis to derive firm $D V A R$.

For each year $t$, consider firm $i$ with productivity, $\phi_{i}$, which uses both domestic $\left(M_{i t}^{D}\right)$ and imported materials $\left(M_{i t}^{I}\right)$, alongside capital $\left(K_{i t}\right)$ and labor $\left(L_{i t}\right)$ to produce output $Y_{i}$, according to the following production production:

$$
\begin{aligned}
Y_{i t} & =\phi_{i} K_{i t}^{\alpha_{K}} L_{i t}^{\alpha_{L}} M_{i t}^{\alpha_{M}} \\
M_{i t} & =\left(M_{i t}^{D \frac{\sigma-1}{\sigma}}+M_{i t}^{I \frac{\sigma-1}{\sigma}}\right)^{\frac{\sigma}{\sigma-1}}, \\
\alpha_{K}+\alpha_{L}+\alpha_{M} & =1 \text { and } \sigma>1 .
\end{aligned}
$$

Each firm faces input prices $\left(r_{t}, w_{t}, P_{t}^{D}, P_{t}^{I}\right)$ for capital, labor, domestic materials, and imported materials. Given (32) it can be shown that the price index of total materials is a constant-elasticity-of-substitution (CES) function over $P_{t}^{D}$ and $P_{t}^{I}$ :

$$
P_{t}^{M}=\left(\left(P_{t}^{D}\right)^{1-\sigma}+\left(P_{t}^{I}\right)^{1-\sigma}\right)^{\frac{1}{1-\sigma}}
$$


Firms' cost minimization implies the following total cost of producing $Y_{i t}$ units of output:

$$
\begin{aligned}
C_{i t}\left(r_{t}, w_{t}, P_{t}^{D}, P_{t}^{I}, Y_{i t}\right) & =\frac{Y_{i t}}{\phi_{i}}\left(\frac{r_{t}}{\alpha_{K}}\right)^{\alpha_{K}}\left(\frac{w_{t}}{\alpha_{L}}\right)^{\alpha_{L}}\left(\frac{P_{t}^{M}}{\alpha_{M}}\right)^{\alpha_{M}}, \text { with } \\
\frac{P_{t}^{M} M_{i t}}{C_{i t}} & =\alpha_{M} .
\end{aligned}
$$

Thus, the marginal cost $\left(c_{i t}\right)$ of producing $Y_{i t}$ units of final goods is

$$
c_{i t}=\frac{\partial C_{i t}}{\partial Y_{i t}}=\frac{1}{\phi_{i}}\left(\frac{r_{t}}{\alpha_{K}}\right)^{\alpha_{K}}\left(\frac{w_{t}}{\alpha_{L}}\right)^{\alpha_{L}}\left(\frac{P_{t}^{M}}{\alpha_{M}}\right)^{\alpha_{M}},
$$

which is constant over output. Note that while input prices and input elasticities are common across all firms within an industry-year, firms have different productivity, $\phi_{i}$, which results in different marginal cost, $c_{i t}$, across firms. Then we can express the share of imported materials in total revenue as:

$$
\begin{aligned}
\frac{P_{t}^{I} M_{i t}^{I}}{P_{i t} Y_{i t}} & =\frac{P_{t}^{I} M_{i t}^{I}}{P_{t}^{M} M_{i t}} \frac{P_{t}^{M} M_{i t}}{C_{i t}} \frac{C_{i t}}{P_{i t} Y_{i t}} \\
& =\frac{P_{t}^{I} M_{i t}^{I}}{P_{t}^{M} M_{i t}} \alpha_{M} \frac{c_{i t}}{P_{i t}} \\
& =\alpha_{M}\left(1-\chi_{i t}\right) \frac{P_{t}^{I} M_{i t}^{I}}{P_{t}^{M} M_{i t}}
\end{aligned}
$$

where $\chi_{i}=\frac{P_{i t}-c_{i t}}{P_{i t}} \in[0,1]$ is the price-cost margin of the firm. ${ }^{56}$

Finally, the share of imported materials in total cost of materials can be obtained by the

${ }^{56}$ Note that price-cost margin, $\chi_{i}$ is closely related to firm's markup, which is usually defined as

$$
\mu_{i}=\frac{P_{i t}}{c_{i t}}=\frac{1}{1-\chi_{i}} .
$$

If price equals marginal cost, as it is in the case of perfect competition, $\chi_{i}$ equals 0 and $\mu_{i}=1$. When $\mu_{i}>1$, then $\chi_{i}>0$. 
following minimization problem:

$$
\begin{array}{r}
\min P_{t}^{I} M_{i t}^{I}+P_{t}^{D} M_{i t}^{D} \\
\text { s.t. } M_{i t}=\left(M_{i t}^{D \frac{\sigma-1}{\sigma}}+M_{i t}^{I \frac{\sigma-1}{\sigma}}\right)^{\frac{\sigma}{\sigma-1}} .
\end{array}
$$

Solving it gives the following ratio of imported material cost to total material cost:

$$
\frac{P_{t}^{I} M_{i t}^{I}}{P_{t}^{M} M_{i t}}=\frac{1}{1+\left(\frac{P_{t}^{I}}{P_{t}^{D}}\right)^{\sigma-1}}
$$

We can then express firm $i$ 's $D V A R$ in period $t$, based on (4), as

$$
D V A R_{i t}=1-\alpha_{M}\left(1-\chi_{i t}\right) \frac{1}{1+\left(\frac{P_{t}^{I}}{P_{t}^{D}}\right)^{\sigma-1}}
$$

According to (36), the determinants of a firm's $D V A R$ can be analyzed as follows:

1. Cross-sectional distribution of the $D V A R$ within an industry-year

Given input prices and elasticities, the cross sectional distribution of $D V A R$ within an industry-year depends on the distribution of firm's price-cost margin, $\chi_{i}$, given that $D V A R$ is an affine transformation of $\chi_{i}$. Thus, within an industry-year, a firm with a higher $\chi_{i}$ will have a higher $D V A R$. Factors that affect the price-cost margin will therefore affect firm DVAR.

- Perfect Competition

If the industry is perfectly competitive, $\chi_{i t}=0, \forall i, t$, the cross-sectional distribution of 
$D V A R$ degenerates to the following constant that does not vary across firms:

$$
D V A R_{i t}=1-\alpha_{M} \frac{1}{1+\left(\frac{P_{t}^{I}}{P_{t}^{D}}\right)^{\sigma-1}}, \forall i, t
$$

- Monopolistic Competition with CES preferences

Under monopolistic competition with CES preferences, $\chi_{i t}=\chi, \forall i$, since markup is constant across all firms, the cross-sectional distribution of $D V A R$ degenerates to the following constant that also does not vary across firms within the same industry:

$$
D V A R_{i t}=1-\alpha_{M}(1-\chi) \frac{1}{1+\left(\frac{P_{t}^{I}}{P_{t}^{D}}\right)^{\sigma-1}}, \forall i, t
$$

Note that the cross-sectional distribution of $D V A R$ does not depend on the distribution of firm productivity under CES preferences, as long as markup is constant across firms. Empirically, if we observe varying $D V A R$ across firms within the same industry-year, it indicates that the CES preference assumption is not supported and that the industry is likely not perfectly competitive.

\section{Time-series movement of $D V A R$ within firms}

Eq. (36) shows that the time-series movement of $D V A R$ is determined by the price of imported inputs to domestic inputs, $\frac{P_{t}^{I}}{P_{t}^{D}}$, which is common across firms within the same industry-year. Factors that affect $\frac{P_{t}^{I}}{P_{t}^{D}}$ will affect a firm's $D V A R$ over time. It is worth emphasizing that factors that do not affect $\frac{P_{t}^{I}}{P_{t}^{D}}$ directly, such as the firm's wages $(w)$ or productivity $\left(\phi_{i}\right)$, do not directly affect the time-series movement of $D V A R$ within firms. ${ }^{57}$

\footnotetext{
${ }^{57}$ Domestic wages can still indirectly affect firm $D V A R$ through affecting the price of domestic materials. In the regression analysis below, controlling for the relative price of materials, we should expect no impact from wages on firm $D V A R$.
} 


\section{References}

[1] Ahn, Jaebin., Amit Khandelwal, and Shang-Jin Wei (2011). "The Role of Intermediaries in Facilitating Trade," Journal of International Economics, 84, 73-85.

[2] Brandt, Loren, Johannes Van Biesebroeck, Yifan Zhang (2012). "Creative Accounting or Creative Destruction? Firm-level Productivity Growth in Chinese Manufacturing," Journal of Development Economics, 97:2, 339-351.

[3] Cebeci, Tolga, Fernandes, Ana, Freund, Caroline. and Martha Pierola (2012). "Exporter Dynamics Database," World Bank Policy Research Working Paper 6229.

[4] Koopman, Robert, Zhi Wang, and Shang-Jin Wei (2012). "Estimating Domestic Content in Exports When Processing Trade Is Pervasive," Journal of Development Economics, 99:1, pp.178-89.

[5] Manova, Kalina and Zhihong Yu (2013). "Firms and Credit Constraints along the Global Value Chain: Processing Trade in China," NBER Working Paper 18561. 
Figure A1: Share of China's Processing Exports, 2000-2007

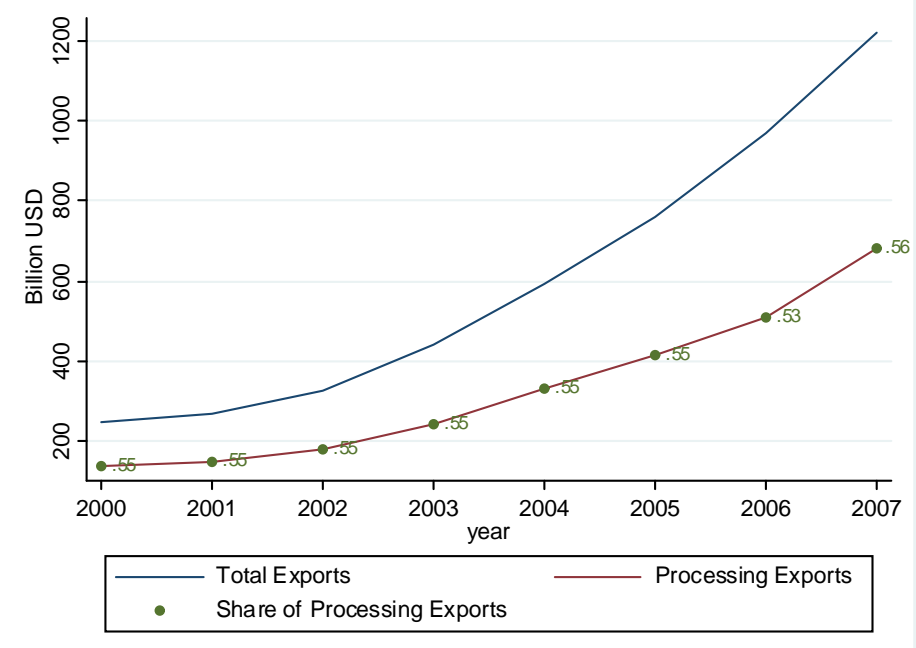


Figure A2: Shares of Processing Exports in China's Top 10 Export Destinations (2000 \& 2007)

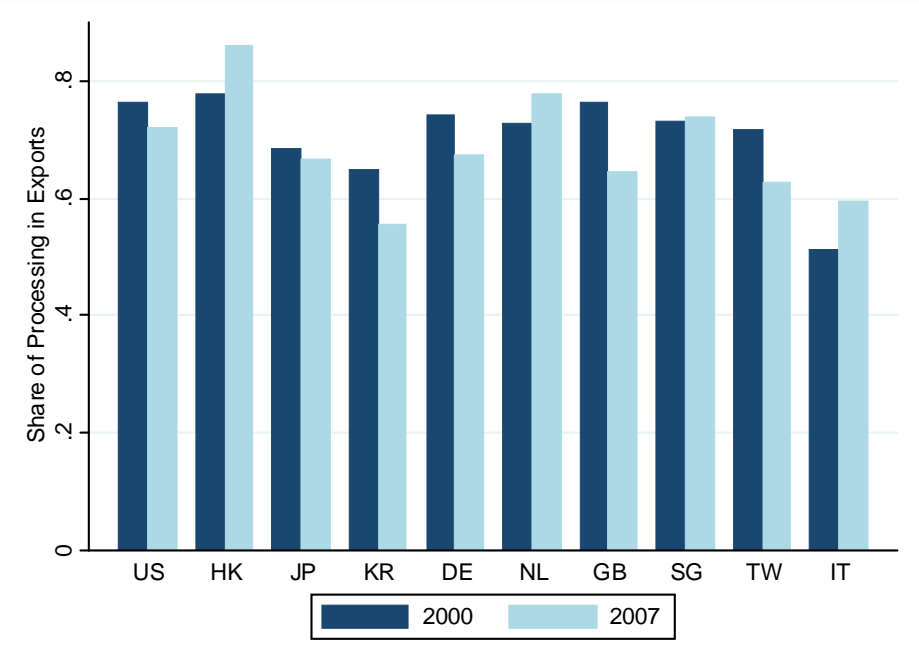


Figure A3: Shares of Processing Exports by Industry Sector (2007)

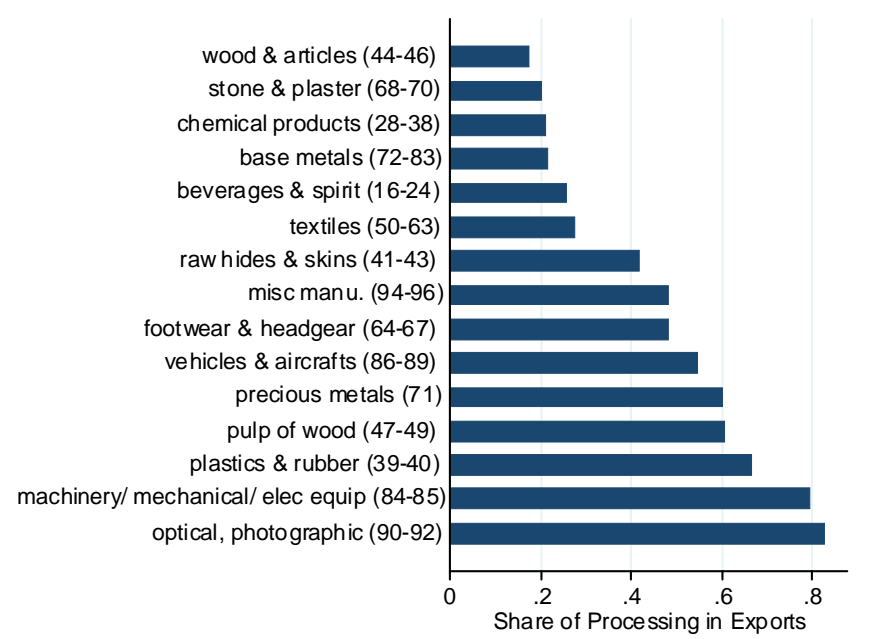

Figure A4: DVAR of Processing Exports - Different Filtered Samples (2000-2007)

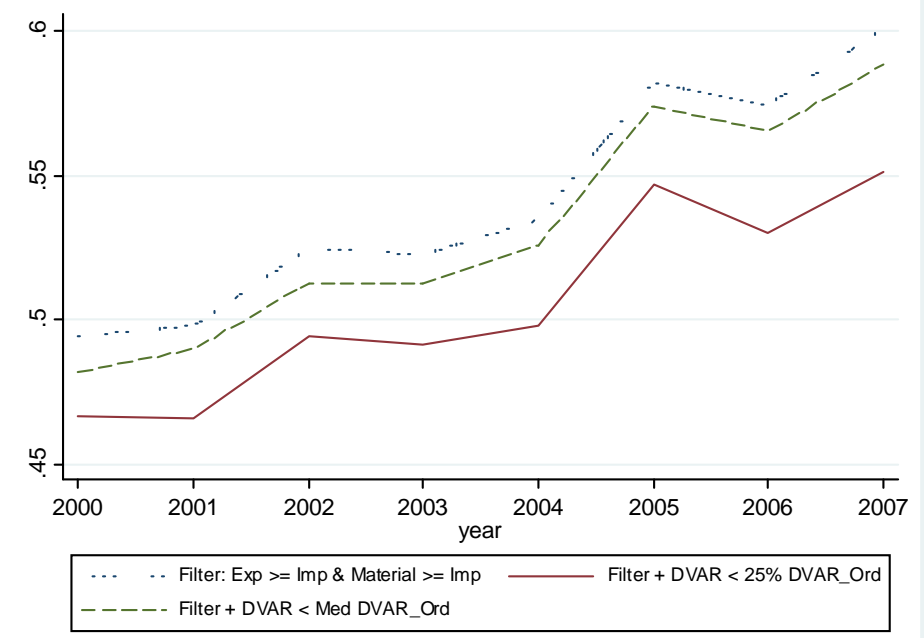


Figure A5: Export Share of the Two Types Processing (2000-2007)

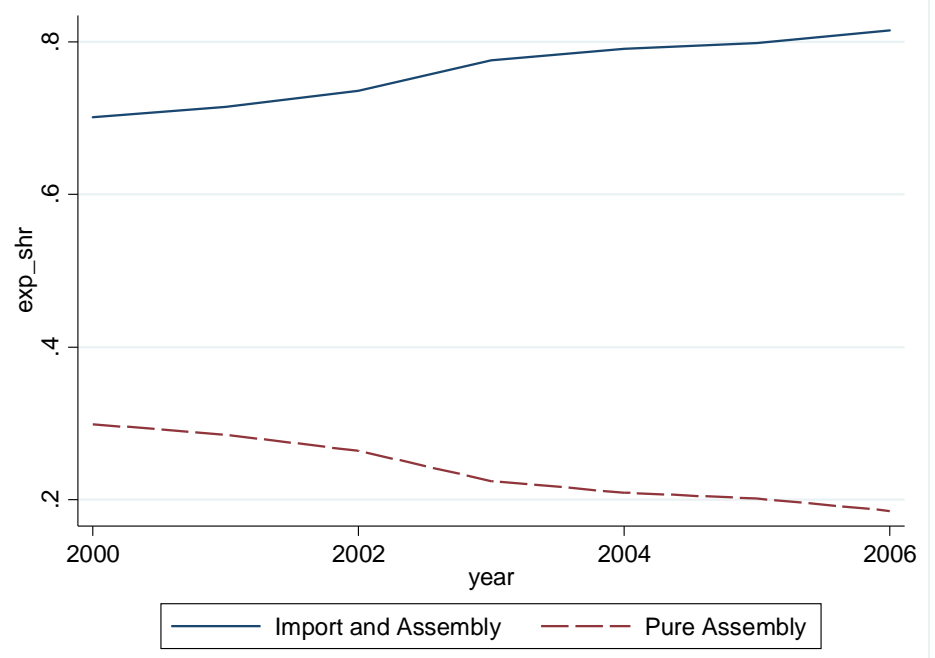

Figure A6: DVAR of Processing Exports (Multi-industry Firms, 2000-2007)

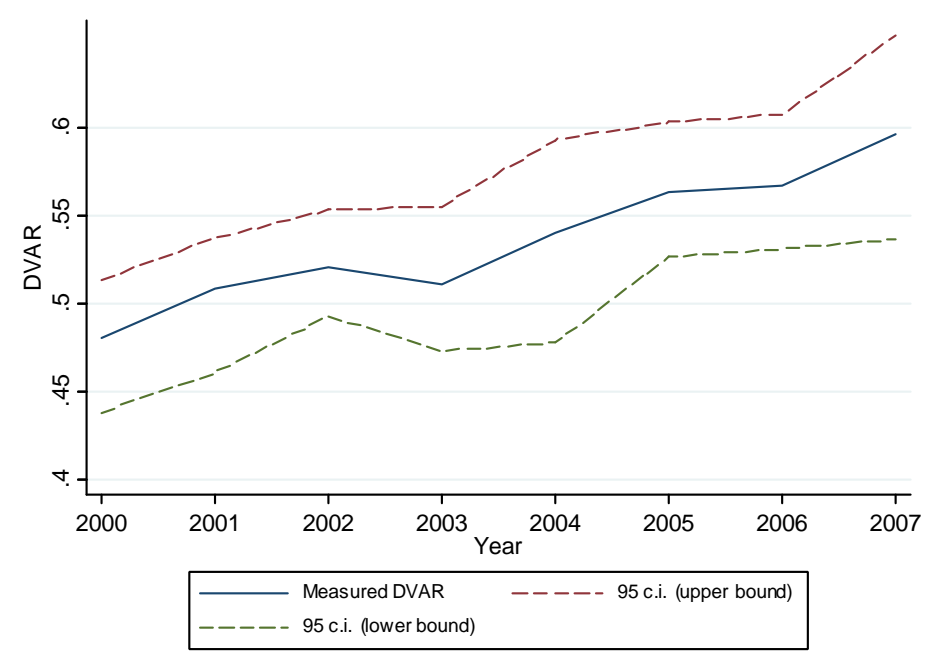


Figure A7: DVAR of Aggregate Exports (Single-industry Firms, 2000-2007)

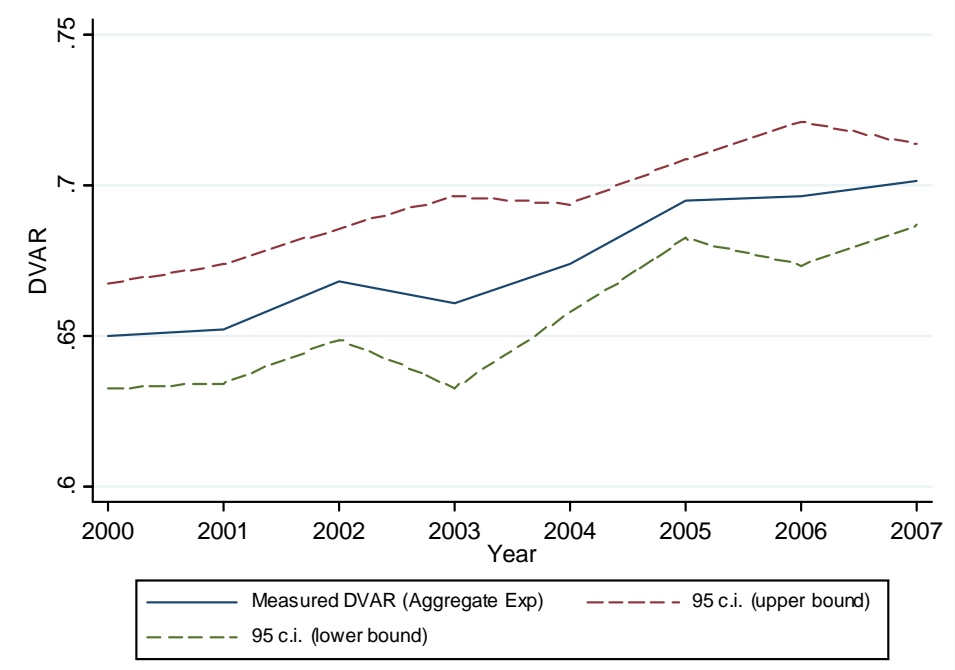


Table A1: Top 10 Destinations of China's Processing Exports

\begin{tabular}{r|lr|lr}
\hline \hline & \multicolumn{2}{|c|}{2000} & \multicolumn{2}{c}{2007} \\
\hline Rank & & USD (Bil) & & USD (Bil) \\
\hline 1 & United States & 35.17 & United States & 152.51 \\
2 & Hong Kong SAR, China & 31.02 & Hong Kong SAR, China & 150.00 \\
3 & Japan & 23.17 & Japan & 60.25 \\
4 & Germany & 5.62 & Netherlands & 29.08 \\
5 & Korea, Republic of & 5.34 & Germany & 29.00 \\
6 & Netherlands & 3.90 & Korea, Republic of & 26.70 \\
7 & United Kingdom & 3.90 & Singapore & 19.04 \\
8 & Singapore & 3.62 & United Kingdom & 17.41 \\
9 & Taiwan, China & 2.92 & Taiwan, China & 13.22 \\
10 & France & 2.10 & France & 11.81 \\
\hline \hline
\end{tabular}

Source: China's Customs Trade Data. 


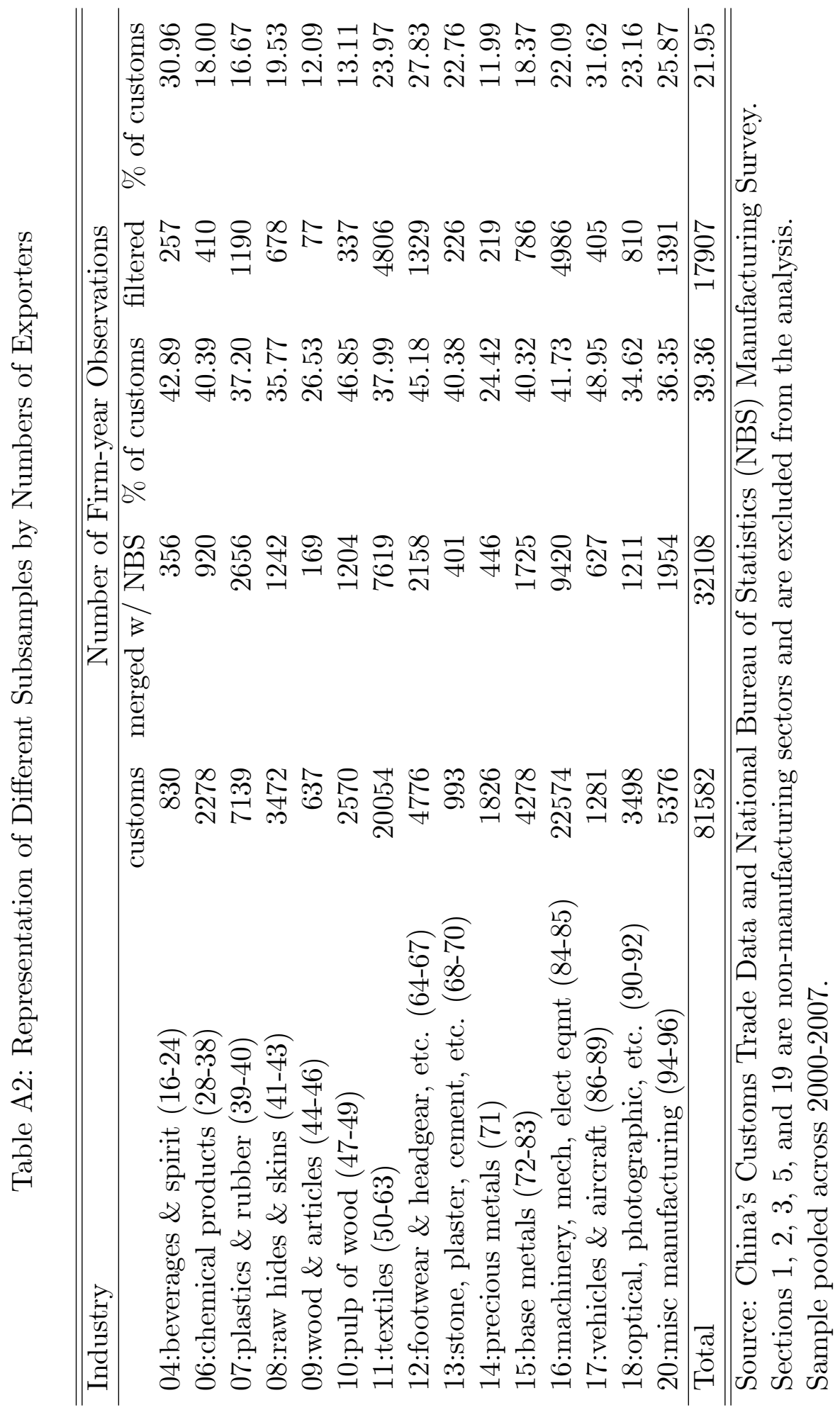




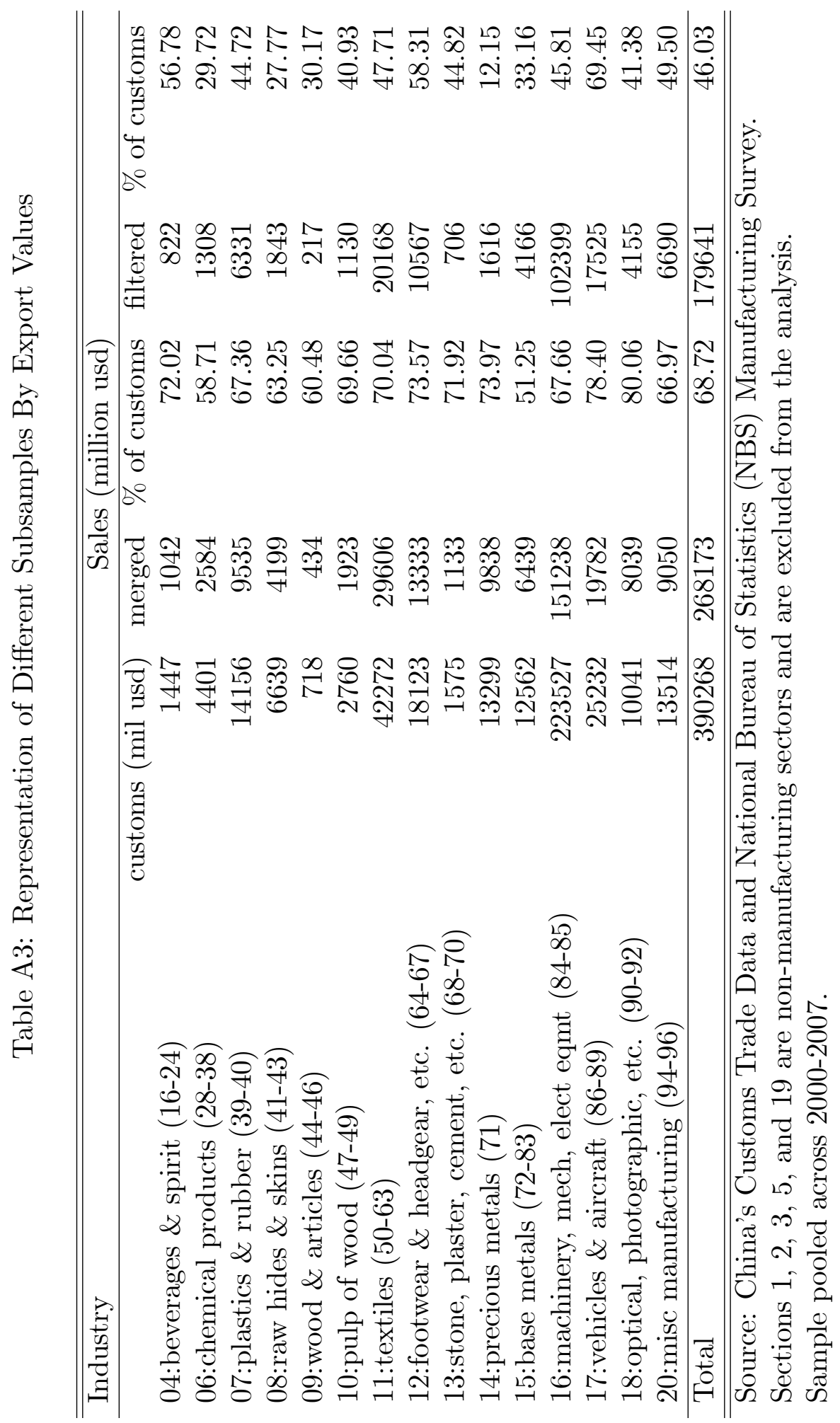


Table A4: Median of Materials to Sales Ratio by Industry and Year

\begin{tabular}{|c|c|c|c|c|c|c|c|c|}
\hline \multirow[t]{2}{*}{ Industry Sector } & \multicolumn{8}{|c|}{ Year } \\
\hline & 2000 & 2001 & 2002 & 2003 & 2004 & 2005 & 2006 & 2007 \\
\hline 04:beverages \& spirit (16-24) & 0.785 & 0.774 & 0.779 & 0.724 & 0.833 & 0.784 & 0.797 & 0.774 \\
\hline 06:chemical products (28-38) & 0.813 & 0.824 & 0.777 & 0.790 & 0.814 & 0.771 & 0.787 & 0.772 \\
\hline 07:plastics \& rubber $(39-40)$ & 0.806 & 0.791 & 0.791 & 0.799 & 0.830 & 0.806 & 0.798 & 0.798 \\
\hline 08:raw hides \& skins (41-43) & 0.806 & 0.810 & 0.788 & 0.766 & 0.772 & 0.792 & 0.763 & 0.741 \\
\hline 09:wood \& articles (44-46) & 0.801 & 0.788 & 0.769 & 0.741 & 0.776 & 0.801 & 0.796 & 0.815 \\
\hline 10:pulp of wood (47-49) & 0.800 & 0.796 & 0.778 & 0.785 & 0.818 & 0.799 & 0.769 & 0.771 \\
\hline 11:textiles $(50-63)$ & 0.791 & 0.782 & 0.770 & 0.771 & 0.769 & 0.758 & 0.753 & 0.736 \\
\hline 12:footwear \& headgear, etc. (64-67) & 0.795 & 0.778 & 0.754 & 0.770 & 0.763 & 0.745 & 0.749 & 0.720 \\
\hline 13:stone, plaster, cement, etc. (68-70) & 0.795 & 0.768 & 0.735 & 0.777 & 0.750 & 0.777 & 0.739 & 0.753 \\
\hline 14:precious metals $(71)$ & 0.780 & 0.754 & 0.739 & 0.749 & 0.744 & 0.711 & 0.724 & 0.762 \\
\hline 15 :base metals $(72-83)$ & 0.826 & 0.817 & 0.797 & 0.782 & 0.812 & 0.791 & 0.787 & 0.810 \\
\hline 16:machinery, mech, elect \& eqmt (84-85) & 0.800 & 0.803 & 0.773 & 0.773 & 0.804 & 0.796 & 0.780 & 0.780 \\
\hline 17:vehicles \& aircraft (86-89) & 0.811 & 0.829 & 0.800 & 0.776 & 0.811 & 0.787 & 0.809 & 0.788 \\
\hline 18:optical, photographic, etc. (90-92) & 0.806 & 0.785 & 0.750 & 0.759 & 0.773 & 0.753 & 0.753 & 0.727 \\
\hline 20:misc manufacturing (94-96) & 0.796 & 0.776 & 0.757 & 0.764 & 0.783 & 0.755 & 0.758 & 0.761 \\
\hline
\end{tabular}

Source: China's Customs Trade Data and National Bureau of Statistics Manufacturing Survey. 
Table A5: Upstream Variety Counts

\begin{tabular}{lcccccccc}
\hline \hline Industry Sector & \multicolumn{1}{c}{ Year } \\
\hline & 2000 & 2001 & 2002 & 2003 & 2004 & 2005 & 2006 & 2007 \\
\cline { 2 - 8 } 01:live animals (1-5) & 287.7 & 288.2 & 292.1 & 289.9 & 291.2 & 293.5 & 291.5 & 293.4 \\
02:vegetables (6-14) & 333.4 & 335.0 & 340.4 & 339.2 & 340.9 & 344.1 & 342.3 & 342.8 \\
03:animal or vegetable oil (15) & 294.2 & 294.5 & 297.9 & 295.6 & 296.4 & 299.2 & 297.3 & 298.0 \\
04:beverages \& spirit (16-24) & 307.3 & 308.4 & 313.3 & 311.7 & 313.2 & 316.2 & 314.3 & 315.3 \\
05:mineral products (25-27) & 253.5 & 256.0 & 258.9 & 261.2 & 262.6 & 265.2 & 266.5 & 265.4 \\
06:chemical products (28-38) & 304.5 & 307.4 & 312.4 & 313.5 & 315.5 & 318.6 & 319.8 & 316.9 \\
07:plastics \& rubber (39-40) & 263.6 & 263.6 & 268.4 & 268.1 & 270.9 & 273.2 & 273.6 & 272.1 \\
08:raw hides \& skins (41-43) & 308.1 & 309.1 & 312.8 & 310.8 & 312.1 & 314.5 & 314.1 & 312.2 \\
09:wood \& articles (44-46) & 186.2 & 188.2 & 192.3 & 192.0 & 194.1 & 195.2 & 193.6 & 193.2 \\
10:pulp of wood (47-49) & 202.6 & 205.3 & 207.3 & 209.4 & 209.6 & 213.3 & 210.8 & 209.8 \\
11:textiles (50-63) & 445.7 & 447.2 & 452.0 & 449.6 & 452.3 & 454.4 & 453.1 & 451.8 \\
12:footwear \& headgear, etc. (64-67) & 374.5 & 374.6 & 378.6 & 376.5 & 379.5 & 381.1 & 380.4 & 378.6 \\
13:stone, plaster, cement, etc. (68-70) & 282.2 & 284.2 & 288.9 & 289.9 & 292.3 & 294.6 & 295.5 & 293.6 \\
14:precious metals (71) & 310.3 & 313.5 & 319.3 & 320.1 & 323.8 & 326.3 & 326.9 & 324.4 \\
15:base metals (72-83) & 348.7 & 352.7 & 359.5 & 361.0 & 366.4 & 369.0 & 370.4 & 367.4 \\
16:machinery, mech, elect eqmt (84-85) & 447.6 & 450.9 & 456.3 & 457.6 & 461.6 & 463.6 & 464.3 & 462.9 \\
17:vehicles \& aircraft (86-89) & 296.4 & 297.3 & 302.6 & 304.7 & 308.1 & 309.4 & 310.9 & 311.0 \\
18:optical, photographic, etc. (90-92) & 421.6 & 424.6 & 430.7 & 430.9 & 435.7 & 437.6 & 438.3 & 435.8 \\
20:misc manufacturing (94-96) & 326.8 & 328.5 & 333.5 & 333.0 & 336.6 & 338.4 & 338.5 & 336.4 \\
\hline \hline
\end{tabular}

Source: China's Customs Trade Data and National Bureau of Statistics Manufacturing Survey. Each variety is defined as a HS-6 digit product. 
Table A6: Price Index of Imported Materials/ Price Index of Domestic Materials

\begin{tabular}{lcccccccc}
\hline Industry Sector & \multicolumn{10}{c}{ Year } \\
\hline & 2000 & 2001 & 2002 & 2003 & 2004 & 2005 & 2006 & 2007 \\
\cline { 2 - 9 } 04:beverages \& spirit (16-24) & 1 & 0.980 & 0.975 & 1.075 & 1.067 & 1.092 & 1.187 & 1.220 \\
06:chemical products (28-38) & 1 & 0.981 & 1.028 & 1.145 & 1.219 & 1.385 & 1.564 & 1.657 \\
07:plastics \& rubber (39-40) & 1 & 0.997 & 1.053 & 1.139 & 1.183 & 1.288 & 1.418 & 1.526 \\
08:raw hides \& skins (41-43) & 1 & 1.000 & 0.997 & 1.098 & 1.125 & 1.192 & 1.279 & 1.355 \\
09:wood \& articles (44-46) & 1 & 0.960 & 0.991 & 1.077 & 1.112 & 1.162 & 1.233 & 1.262 \\
10:pulp of wood (47-49) & 1 & 0.998 & 1.024 & 1.116 & 1.168 & 1.241 & 1.332 & 1.486 \\
11:textiles (50-63) & 1 & 0.995 & 1.004 & 1.087 & 1.108 & 1.153 & 1.228 & 1.253 \\
12:footwear \& headgear, etc. (64-67) & 1 & 0.994 & 1.019 & 1.101 & 1.150 & 1.234 & 1.328 & 1.396 \\
13:stone, plaster, cement, etc. (68-70) & 1 & 0.996 & 1.007 & 1.095 & 1.197 & 1.356 & 1.510 & 1.659 \\
14:precious metals (71) & 1 & 0.985 & 0.960 & 1.048 & 1.094 & 1.208 & 1.316 & 1.403 \\
15:base metals (72-83) & 1 & 0.978 & 0.991 & 1.043 & 1.112 & 1.256 & 1.403 & 1.488 \\
16:machinery, mech, elect eqmt (84-85) & 1 & 1.021 & 1.115 & 1.237 & 1.305 & 1.431 & 1.572 & 1.890 \\
17:vehicles \& aircraft (86-89) & 1 & 1.044 & 1.053 & 1.136 & 1.245 & 1.390 & 1.547 & 1.890 \\
18:optical, photographic, etc. (90-92) & 1 & 1.015 & 1.120 & 1.299 & 1.416 & 1.541 & 1.672 & 2.022 \\
20:misc manufacturing (94-96) & 1 & 0.992 & 1.009 & 1.105 & 1.175 & 1.286 & 1.413 & 1.563 \\
\hline
\end{tabular}

Source: China's Customs Trade Data and National Bureau of Statistics Manufacturing Survey. Both prices are normalized to 1 for year 2000 .

Table A7: Percentage of Foreign Content in Domestic Materials

\begin{tabular}{lcccccccc}
\hline \hline Industry Sector & \multicolumn{1}{c}{ Year } \\
\hline & 2000 & 2001 & 2002 & 2003 & 2004 & 2005 & 2006 & 2007 \\
\cline { 2 - 8 } 04:beverages \& spirit (16-24) & 0.727 & 0.795 & 0.960 & 1.176 & 1.560 & 2.032 & 2.029 & 2.084 \\
06:chemical products (28-38) & 0.670 & 0.744 & 0.921 & 1.151 & 1.595 & 2.134 & 2.183 & 2.318 \\
07:plastics \& rubber (39-40) & 0.386 & 0.433 & 0.544 & 0.691 & 0.975 & 1.312 & 1.374 & 1.466 \\
08:raw hides \& skins (41-43) & 0.718 & 0.788 & 0.972 & 1.210 & 1.652 & 2.169 & 2.210 & 2.291 \\
09:wood \& articles (44-46) & 1.110 & 1.209 & 1.465 & 1.826 & 2.518 & 3.353 & 3.352 & 3.493 \\
10:pulp of wood (47-49) & 0.892 & 1.012 & 1.286 & 1.680 & 2.389 & 3.211 & 3.374 & 3.549 \\
11:textiles (50-63) & 1.058 & 1.163 & 1.443 & 1.800 & 2.436 & 3.226 & 3.288 & 3.426 \\
12:footwear \& headgear, etc. (64-67) & 0.927 & 1.027 & 1.290 & 1.631 & 2.263 & 3.023 & 3.133 & 3.293 \\
13:stone, plaster, cement, etc. (68-70) & 1.204 & 1.338 & 1.662 & 2.094 & 2.944 & 3.967 & 4.103 & 4.381 \\
14:precious metals (71) & 0.918 & 1.024 & 1.276 & 1.607 & 2.249 & 3.053 & 3.188 & 3.450 \\
15:base metals (72-83) & 1.146 & 1.282 & 1.602 & 2.026 & 2.857 & 3.907 & 4.122 & 4.511 \\
16:machinery, mech, elect eqmt (84-85) & 1.089 & 1.230 & 1.544 & 1.974 & 2.737 & 3.689 & 3.939 & 4.375 \\
17:vehicles \& aircraft (86-89) & 1.414 & 1.586 & 1.981 & 2.528 & 3.564 & 4.855 & 5.134 & 5.657 \\
18:optical, photographic, etc. (90-92) & 0.730 & 0.820 & 1.028 & 1.311 & 1.829 & 2.466 & 2.617 & 2.877 \\
20:misc manufacturing (94-96) & 1.015 & 1.129 & 1.412 & 1.787 & 2.502 & 3.366 & 3.513 & 3.759 \\
\hline \hline
\end{tabular}

Source: From Koopman, Wang, and Wei (2012) and authors' imputation based on the growth rate of the number of ordinary importers 
Table A8: 25th-percentile of Ordinary Exporters' DVAR by Industry and Year

\begin{tabular}{lcccccccc}
\hline \hline Industry Sector & \multicolumn{1}{c}{ Year } \\
\hline & 2000 & 2001 & 2002 & 2003 & 2004 & 2005 & 2006 & 2007 \\
\cline { 2 - 9 } 04:beverages \& spirit (16-24) & 0.909 & 0.928 & 0.897 & 0.884 & 0.876 & 0.922 & 0.911 & 0.931 \\
06:chemical products (28-38) & 0.880 & 0.906 & 0.895 & 0.942 & 0.880 & 0.914 & 0.904 & 0.915 \\
07:plastics \& rubber (39-40) & 0.811 & 0.862 & 0.853 & 0.838 & 0.795 & 0.845 & 0.849 & 0.848 \\
08:raw hides \& skins (41-43) & 0.792 & 0.846 & 0.876 & 0.894 & 0.870 & 0.792 & 0.803 & 0.777 \\
09:wood \& articles (44-46) & 0.820 & 0.848 & 0.855 & 0.878 & 0.859 & 0.898 & 0.870 & 0.901 \\
10:pulp of wood (47-49) & 0.804 & 0.850 & 0.826 & 0.873 & 0.775 & 0.946 & 0.893 & 0.895 \\
11:textiles (50-63) & 0.802 & 0.852 & 0.855 & 0.873 & 0.858 & 0.890 & 0.893 & 0.891 \\
12:footwear \& headgear, etc. (64-67) & 0.756 & 0.789 & 0.792 & 0.855 & 0.804 & 0.870 & 0.823 & 0.888 \\
13:stone, plaster, cement, etc. (68-70) & 0.942 & 0.889 & 0.912 & 0.907 & 0.861 & 0.876 & 0.877 & 0.892 \\
14:precious metals (71) & 1.000 & 1.000 & 1.000 & 1.000 & 1.000 & 1.000 & 1.000 & 1.000 \\
15:base metals (72-83) & 0.851 & 0.861 & 0.896 & 0.916 & 0.876 & 0.917 & 0.926 & 0.953 \\
16:machinery, mech, elect eqmt (84-85) & 0.830 & 0.833 & 0.841 & 0.893 & 0.836 & 0.900 & 0.910 & 0.915 \\
17:vehicles \& aircraft (86-89) & 0.944 & 0.971 & 0.978 & 0.967 & 0.943 & 0.980 & 0.982 & 0.989 \\
18:optical, photographic, etc. (90-92) & 0.808 & 0.867 & 0.843 & 0.882 & 0.897 & 0.901 & 0.915 & 0.915 \\
20:misc manufacturing (94-96) & 0.730 & 0.804 & 0.892 & 0.901 & 0.899 & 0.912 & 0.932 & 0.923 \\
\hline \hline
\end{tabular}

Source: China's Customs Trade Data and National Bureau of Statistics Manufacturing Survey.

Table A9: DVAR by Industry and Year

\begin{tabular}{lcccccccc}
\hline \hline Industry Sector & \multicolumn{1}{c}{ Year } \\
\hline & 2000 & 2001 & 2002 & 2003 & 2004 & 2005 & 2006 & 2007 \\
\cline { 2 - 8 } 04:beverages \& spirit (16-24) & 0.650 & 0.685 & 0.699 & 0.694 & 0.725 & 0.680 & 0.732 & 0.750 \\
06:chemical products (28-38) & 0.386 & 0.463 & 0.500 & 0.481 & 0.384 & 0.452 & 0.564 & 0.443 \\
07:plastics \& rubber (39-40) & 0.418 & 0.458 & 0.364 & 0.403 & 0.357 & 0.507 & 0.417 & 0.443 \\
08:raw hides \& skins (41-43) & 0.426 & 0.343 & 0.410 & 0.418 & 0.504 & 0.525 & 0.531 & 0.573 \\
09:wood \& articles (44-46) & 0.438 & 0.604 & 0.445 & 0.289 & 0.552 & 0.594 & 0.347 & 0.390 \\
10:pulp of wood (47-49) & 0.304 & 0.401 & 0.395 & 0.393 & 0.452 & 0.547 & 0.562 & 0.515 \\
11:textiles (50-63) & 0.495 & 0.464 & 0.525 & 0.546 & 0.558 & 0.599 & 0.620 & 0.561 \\
12:footwear \& headgear, etc. (64-67) & 0.590 & 0.571 & 0.613 & 0.663 & 0.628 & 0.657 & 0.686 & 0.693 \\
13:stone, plaster, cement, etc. (68-70) & 0.550 & 0.517 & 0.538 & 0.617 & 0.587 & 0.504 & 0.530 & 0.554 \\
14:precious metals (71) & 0.248 & 0.262 & 0.094 & 0.306 & 0.531 & 0.291 & 0.504 & 0.528 \\
15:base metals (72-83) & 0.525 & 0.468 & 0.545 & 0.477 & 0.556 & 0.356 & 0.426 & 0.491 \\
16:machinery, mech, elect eqmt (84-85) & 0.402 & 0.428 & 0.467 & 0.436 & 0.489 & 0.540 & 0.479 & 0.529 \\
17:vehicles \& aircraft (86-89) & 0.501 & 0.657 & 0.507 & 0.628 & 0.554 & 0.617 & 0.721 & 0.767 \\
18:optical, photographic, etc. (90-92) & 0.469 & 0.530 & 0.509 & 0.529 & 0.463 & 0.574 & 0.641 & 0.558 \\
20:misc manufacturing (94-96) & 0.617 & 0.572 & 0.599 & 0.606 & 0.620 & 0.584 & 0.663 & 0.650 \\
\hline \hline
\end{tabular}

Source: China's Customs Trade Data and National Bureau of Statistics Manufacturing Survey DVAR is computed using single-industry firm sample and Filter 2 stated in Table 3. 


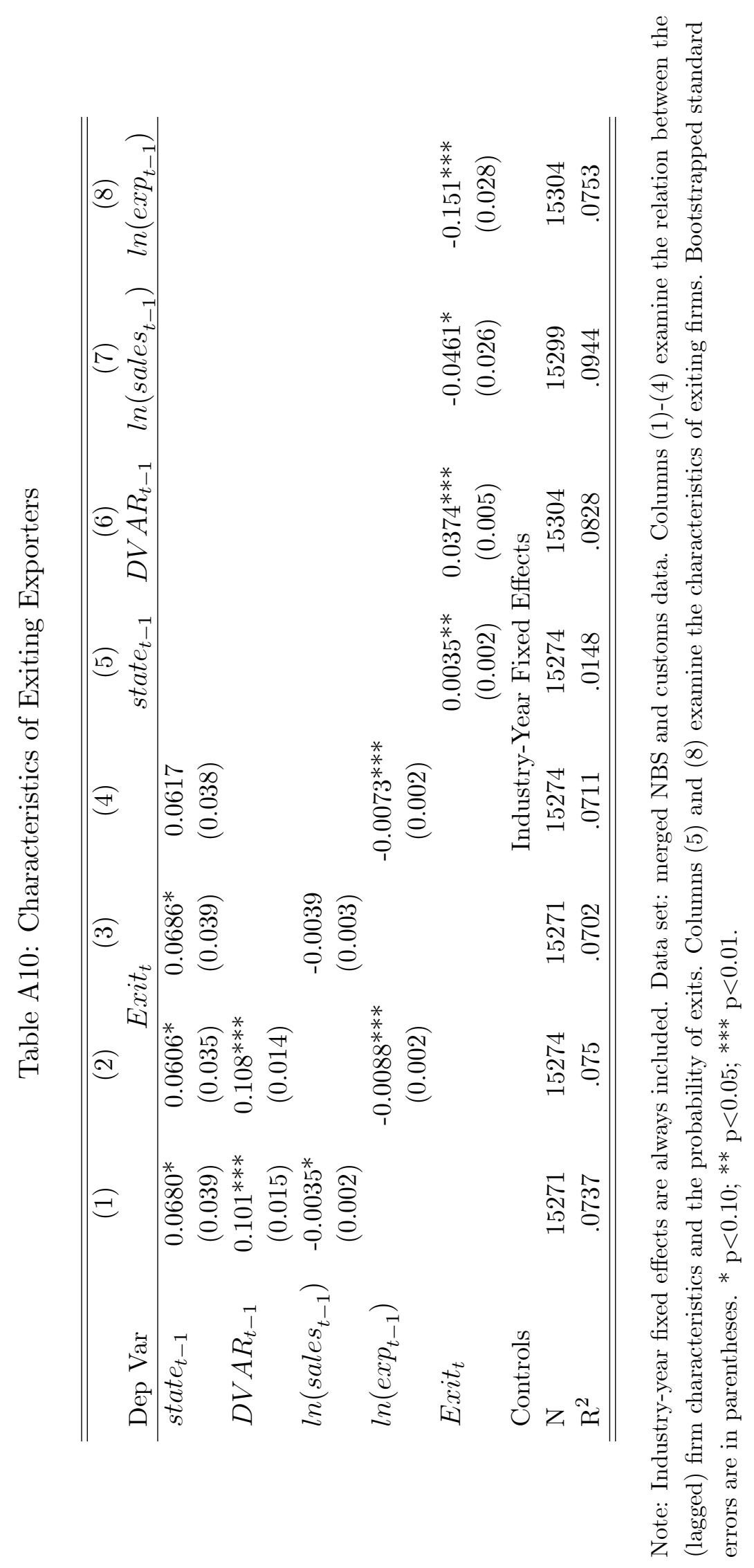


Table A11: Import and Assembly versus Pure Assembly

\begin{tabular}{|c|c|c|c|c|c|c|c|c|}
\hline \multirow{3}{*}{$\begin{array}{l}\text { Dep. Var. } \\
\text { Sample: }\end{array}$} & (1) & (2) & (3) & (4) & (5) & (6) & (7) & (8) \\
\hline & \multicolumn{2}{|c|}{ DVAR } & \multicolumn{2}{|c|}{ Imp/Material } & \multicolumn{2}{|c|}{$\ln ($ Exp Variety $)$} & \multicolumn{2}{|c|}{$\ln (\operatorname{Imp}$ variety $)$} \\
\hline & IA & PA & IA & PA & IA & PA & IA & PA \\
\hline \multicolumn{9}{|l|}{ Year Dummies: } \\
\hline 2001 & $\begin{array}{c}0.0298^{* * *} \\
(0.007)\end{array}$ & $\begin{array}{l}0.0237 \\
(0.032)\end{array}$ & $\begin{array}{c}-0.0232^{* * *} \\
(0.007)\end{array}$ & $\begin{array}{c}0.00386 \\
(0.033)\end{array}$ & $\begin{array}{c}-0.123^{* * *} \\
(0.019)\end{array}$ & $\begin{array}{l}-0.0524 \\
(0.101)\end{array}$ & $\begin{array}{c}-0.0366^{*} \\
(0.022)\end{array}$ & $\begin{array}{r}-0.0264 \\
(0.088)\end{array}$ \\
\hline 2002 & $\begin{array}{c}0.0494^{* * *} \\
(0.008)\end{array}$ & $\begin{array}{l}0.0422 \\
(0.034)\end{array}$ & $\begin{array}{c}-0.0295^{* * *} \\
(0.007)\end{array}$ & $\begin{array}{l}0.0359 \\
(0.035)\end{array}$ & $\begin{array}{c}-0.114^{* * *} \\
(0.020)\end{array}$ & $\begin{array}{r}-0.0604 \\
(0.106)\end{array}$ & $\begin{array}{c}0.0601^{* *} \\
(0.024)\end{array}$ & $\begin{array}{l}0.0335 \\
(0.093)\end{array}$ \\
\hline 2003 & $\begin{array}{c}0.0682^{* * * *} \\
(0.007)\end{array}$ & $\begin{array}{l}0.0618^{*} \\
(0.034)\end{array}$ & $\begin{array}{c}-0.0700^{* * *} \\
(0.007)\end{array}$ & $\begin{array}{l}0.00539 \\
(0.038)\end{array}$ & $\begin{array}{c}-0.224^{* * *} \\
(0.021)\end{array}$ & $\begin{array}{r}-0.0959 \\
(0.107)\end{array}$ & $\begin{array}{c}0.101^{* * *} \\
(0.023)\end{array}$ & $\begin{array}{c}0.119 \\
(0.093)\end{array}$ \\
\hline 2004 & $\begin{array}{c}0.0706^{* * * *} \\
(0.008)\end{array}$ & $\begin{array}{l}0.0486 \\
(0.032)\end{array}$ & $\begin{array}{c}-0.0917^{* * *} \\
(0.008)\end{array}$ & $\begin{array}{l}0.0271 \\
(0.044)\end{array}$ & $\begin{array}{c}-0.286^{* * *} \\
(0.022)\end{array}$ & $\begin{array}{l}-0.133 \\
(0.106)\end{array}$ & $\begin{array}{c}0.118^{* * * *} \\
(0.024)\end{array}$ & $\begin{array}{l}0.217^{* *} \\
(0.096)\end{array}$ \\
\hline 2005 & $\begin{array}{c}0.0980^{* * * *} \\
(0.008)\end{array}$ & $\begin{array}{c}0.100^{* * *} \\
(0.034)\end{array}$ & $\begin{array}{c}-0.118^{* * * *} \\
(0.009)\end{array}$ & $\begin{array}{r}-0.0290 \\
(0.047)\end{array}$ & $\begin{array}{c}-0.349 * * * \\
(0.024)\end{array}$ & $\begin{array}{c}-0.221^{* *} \\
(0.107)\end{array}$ & $\begin{array}{c}0.203^{* * *} \\
(0.025)\end{array}$ & $\begin{array}{c}0.228^{* *} \\
(0.105)\end{array}$ \\
\hline 2006 & $\begin{array}{c}0.140^{* * *} \\
(0.008)\end{array}$ & $\begin{array}{c}0.132^{* * *} \\
(0.038)\end{array}$ & $\begin{array}{c}-0.161^{* * *} \\
(0.010)\end{array}$ & $\begin{array}{r}-0.0467 \\
(0.045)\end{array}$ & $\begin{array}{c}-0.202^{* * *} \\
(0.025)\end{array}$ & $\begin{array}{l}-0.136 \\
(0.106)\end{array}$ & $\begin{array}{c}0.283^{* * *} \\
(0.029)\end{array}$ & $\begin{array}{c}0.285^{* * *} \\
(0.102)\end{array}$ \\
\hline$\left(\frac{w L}{P Y}\right)_{i t}$ & $\begin{array}{c}-0.0044 \\
(0.016)\end{array}$ & $\begin{array}{l}0.0009 \\
(0.065)\end{array}$ & $\begin{array}{l}0.0270 \\
(0.052)\end{array}$ & $\begin{array}{l}0.251^{*} \\
(0.136)\end{array}$ & $\begin{array}{c}-0.0343 \\
(0.055)\end{array}$ & $\begin{array}{l}-0.231 \\
(0.226)\end{array}$ & $\begin{array}{l}-0.0417 \\
(0.037)\end{array}$ & $\begin{array}{l}0.0059 \\
(0.241)\end{array}$ \\
\hline$\left(\frac{P^{D} M^{D}+P^{I} M^{I}}{P Y}\right)_{i t}$ & $\begin{array}{c}-0.0247^{* * *} \\
(0.009)\end{array}$ & $\begin{array}{l}0.0073 \\
(0.058)\end{array}$ & & & $\begin{array}{l}0.0143 \\
(0.025)\end{array}$ & $\begin{array}{l}-0.0867 \\
(0.164)\end{array}$ & $\begin{array}{l}0.0097 \\
(0.026)\end{array}$ & $\begin{array}{l}-0.123 \\
(0.224)\end{array}$ \\
\hline $\ln (K / L)_{i t}$ & & & $\begin{array}{r}-0.0037 \\
(0.005)\end{array}$ & $\begin{array}{l}-0.0071 \\
(0.011)\end{array}$ & & & & \\
\hline $\mathrm{N}$ & 13062 & 1744 & 13040 & 1733 & 13062 & 1744 & 13062 & 1744 \\
\hline $\mathrm{R}^{2}$ & .0686 & .0459 & .0867 & .0579 & .0647 & .0208 & .0419 & 0372 \\
\hline
\end{tabular}

Note: Firm and year fixed effects are always included. Data set: merged NBS-customs data. IA and PA stand for import and assembly and pure assembly, respectively. Columns (1) and (2) use firm DVAR as the dependent variable; columns (3) and (4) use firm imports-to-materials ratio as the dependent variable; columns (5) and (6) use log of the firm's export varieity as the dependent variable; columns (7) and (8) use $\log$ of the firm's export varieity as the dependent variable. Bootstrapped standard errors are in parentheses. ${ }^{*} \mathrm{p}<0.10$; ${ }^{* *} \mathrm{p}<0.05 ;{ }^{* * *} \mathrm{p}<0.01$. 
Table A12: Products that used to be imported by processing exporters but not exported by ordinary exporters in 2000

\begin{tabular}{|c|c|c|c|c|c|}
\hline Rank & HS6 (96) & Description & $\operatorname{Imp00}$ & Exp07 & $\%$ Exp07 by FIE \\
\hline 1 & 740200 & Unrefined copper; copper anodes & 94775.05 & 1.785 & 1.5 \\
\hline 2 & 530121 & Broken and scutched & 69219.71 & 73.338 & 0.0 \\
\hline 3 & 740311 & Refined copper - Cathododes & 52945.12 & 115.669 & 0.0 \\
\hline 4 & 510130 & Carbonised & 47167.51 & 4099.934 & 19.2 \\
\hline 5 & 291733 & Aromatic polycarboxylic acids & 22195.56 & 71.764 & 63.5 \\
\hline 6 & 740321 & Copper alloys - Copper-zinc base alloys & 13405.72 & 21.957 & 5.0 \\
\hline 7 & 710610 & Powder & 10303.45 & 6269.82 & 47.3 \\
\hline 8 & 291412 & Acyclic ketones without oxygen function & 9354.077 & 20100.525 & 13.8 \\
\hline 9 & 740329 & Other copper alloys & 8589.997 & 250.009 & 1.2 \\
\hline 10 & 410122 & Other hides and skins of bovine animals & 7923.013 & 409.437 & 91.7 \\
\hline 11 & 30375 & Other fish, excluding livers and roes & 7108.482 & 403.583 & 18.1 \\
\hline 12 & 470720 & Other paper or paperboard & 5220.848 & 57.024 & 0.0 \\
\hline 13 & 750712 & Tubes and pipes - of nickel & 4757.735 & 1073.887 & 1.5 \\
\hline 14 & 750511 & Bars, rods and profiles, of nickel & 4255.77 & 87.14 & 0.0 \\
\hline 15 & 721113 & Not further worked than hot-rolled & 3560.055 & 1737.362 & 0.0 \\
\hline 16 & 400260 & Isoprene rubber (IR) & 3206.528 & 2492.855 & 0.6 \\
\hline 17 & 870423 & Other, with compression-ignition & 2527.633 & 796856.69 & 8.4 \\
\hline 18 & 481031 & Kraft paper and paperboar & 2410.466 & 2424.858 & 2.1 \\
\hline 19 & 370120 & Instant print film & 2332.919 & 351.927 & 0.0 \\
\hline 20 & 370256 & Other film, for colour photography & 2135.713 & 55.455 & 0.0 \\
\hline 21 & 722530 & Other, not further worked & 2130.281 & 69535.009 & 10.3 \\
\hline 22 & 40110 & Of a fat content & 2022.768 & 0.023 & 100.0 \\
\hline 23 & 40410 & Whey and modified whey & 1992.98 & 0.71 & 0.0 \\
\hline 24 & 721020 & Plated or coated with lead & 1506.084 & 2511.163 & 0.9 \\
\hline 25 & 540342 & Other yarn, multiple or cabled & 1413.818 & 80.048 & 7.3 \\
\hline 26 & 530129 & Flax, broken, scutched, hackled - other & 1163.462 & 135.442 & 49.7 \\
\hline 27 & 370510 & For offset reproduction & 1067.683 & 91.158 & 10.4 \\
\hline 28 & 740312 & Refined copper - Wire-bars & 1028.783 & 0.455 & 100.0 \\
\hline 29 & 370231 & Other film, without perforations & 888.111 & 38.389 & 0.0 \\
\hline 30 & 480240 & Wallpaper base & 772.938 & 6382.673 & 28.0 \\
\hline 31 & 80221 & Hazelnuts or filberts & 617.869 & 5.9 & 0.0 \\
\hline 32 & 50710 & Ivory; ivory powder and waste & 540.557 & 20.158 & 0.0 \\
\hline 33 & 151329 & Palm kernel or babassu oil & 445.65 & 24.453 & 99.4 \\
\hline 34 & 80211 & Almonds - In shell & 376.58 & 3.5 & 0.0 \\
\hline 35 & 890392 & Motorboats, other than outboard & 360 & 607.729 & 0.0 \\
\hline 36 & 841013 & Hydraulic turbines and water wheels & 300 & 2133.552 & 0.0 \\
\hline
\end{tabular}




\begin{tabular}{llllll}
\hline \hline Rank & HS6 (96) & Description & Imp00 & Exp07 & \% Exp07 by FIE \\
\hline & & & & & \\
37 & 293211 & Compounds containing unfused furan ring & 298.517 & 3480.953 & 62.8 \\
38 & 30541 & Smoked fish, including filletsi & 268.626 & 51.527 & 15.2 \\
39 & 290121 & Unsaturated - Ethylene & 228.697 & 53980.444 & 62.4 \\
40 & 720450 & Remelting scrap ingots & 213.786 & 0.15 & 0.0 \\
41 & 320120 & Wattle extract & 186.009 & 4.052 & 61.1 \\
42 & 330112 & Essential oils of citrus fruit & 182.584 & 216.775 & 14.5 \\
43 & 180320 & Wholly or partly defatted & 132.859 & 3.155 & 100.0 \\
44 & 220860 & Vodka & 70.474 & 110.711 & 83.5 \\
45 & 382313 & Industrial monocarboxylic fatty acids & 60.583 & 58.399 & 0.0 \\
46 & 151229 & Cotton-seed oil and its fractions & 51.215 & 1788.796 & 55.8 \\
47 & 520625 & Single yarn, of combed fibres & 50.501 & 721.513 & 1.0 \\
48 & 470319 & Unbleached - Non-coniferous & 40.203 & 97.423 & 0.0 \\
49 & 271129 & In gaseous state - Other & 39.653 & 14.256 & 18.4 \\
50 & 722720 & Of silico-manganese steel & 37.912 & 48480.139 & 17.5 \\
51 & 180310 & Not defatted & 37.019 & 1449.275 & 51.3 \\
52 & 550520 & Of artificial fibres & 33.626 & 195.591 & 7.0 \\
53 & 150300 & Lard stearin, lard oil, oleostearin & 32.134 & 1.57 & 100.0 \\
54 & 20319 & Fresh or chilled - Other & 28.441 & 25052.286 & 0.0 \\
55 & 292213 & Amino-alcohols, their ethers and esters & 25.68 & 58.781 & 0.0 \\
56 & 711510 & Catalysts in the form of wire cloth & 18.672 & 0.432 & 0.0 \\
57 & 151000 & Other oils and their fractions & 14.377 & 0.035 & 0.0 \\
58 & 151521 & Maize (corn) oil and its fractions & 11.338 & 20758.875 & 22.8 \\
59 & 151110 & Crude oil & 9.91 & 0.137 & 0.0 \\
60 & 262011 & Containing mainly zinc & 7.8 & 226.859 & 0.0 \\
61 & 180400 & Cocoa butter, fat and oil & 6.861 & 27570.497 & 45.3 \\
62 & 270730 & Xylole & 6.047 & 41.119 & 0.0 \\
63 & 630631 & Sails - Of synthetic fibres & 5 & 1073.53 & 0.0 \\
64 & 722592 & Otherwise plated or coated w/ zinc & 1.681 & 1002.997 & 0.0 \\
65 & 252230 & Hydraulic lime & 1.344 & 11.135 & 0.0 \\
66 & 310229 & Ammonium sulphate; double salts & 0.992 & 155.239 & 0.0 \\
67 & 854340 & Electric fence energisers & 0.54 & 441628.86 & 25.1 \\
\hline Total & & & 392,126 & $1,546,760$ & 16.63 \\
\hline \hline & & & & & \\
\hline
\end{tabular}

Imp00 is the value of imports by processing exporters in 2000, in thousands USD.

Exp07 is the value of exports by non-processing exporters in 2007, in thousands USD. 